Katherine Ashley $\quad \operatorname{IRSS} 36$ (2011)

\title{
“AE Thoosand Tongues": LANGUAge AND IDENTITY IN PSYCHORAAG
}

\author{
Katherine Ashley*
}

With the twirl of my tongue I encompass words and volumes of worlds. ${ }^{1}$

One of the most distinctive features of Scottish literature is its multilingual tradition. Many bilingual or trilingual Scottish writers have drawn on the resources of the country's indigenous languages - Gaelic, Scots, and English - either publishing in more than one language, like Iain Crichton Smith, or incorporating several languages into one text, as Kevin MacNeil does in The Stornoway Way (2005). In recent years, Gaelic, Scots, and English have been joined by the languages of Scotland's immigrant communities, and authors like Suhayl Saadi have made full use of the country's linguistic situation in order to renegotiate Scottish identity at the turn of the twenty-first century. Saadi's Psychoraag (2004), one of the first Asian-Scots novels, takes place in Glasgow during the final transmission of a short-lived community radio station,

* Katherine Ashley has a PhD in French from the University of Edinburgh, and has taught French, English, and Humanities courses at universities in Canada and Scotland. Her research interests lie in nineteenth- and twentieth-century French and British (particularly Scottish) literature. She is the author of Edmond de Goncourt and the Novel: Naturalism and Decadence, the editor of Prix Goncourt, 1903-2003: essais critiques, and the co-editor of Carver Across the Curriculum: Interdisciplinary Approaches to Teaching the Fiction and Poetry of Raymond Carver. 
Radio Chaandni. The main character, Zaf, is a ScotsPakistani disc jockey with a degree in ethnology. As he hosts the concluding six-hour broadcast of The Junnune Show (The Show of Madness), his thoughts race from past, present, to future, continent to continent, from his parents' early life in Lahore, to his own life in Glasgow's "Wee Faisalabad." Caught up in this cultural and linguistic flux, Zaf searches for a sense of identity, and what makes his search particularly captivating is how this identity is conceptualized through both verbal language and music. ${ }^{3}$ Music, for Zaf, is a way of transcending cultural and linguistic divisions. In Zaf's case, it is a means of harmonizing the seeming paradox of being both Scottish and Pakistani. He is a "man ae a thoosand tongues,"4 a human tower of Babel. "Ah've goat loads ae tongues in ma heid," he states, "thu're aw there, wagglin away, almost singin. A babble." "Furthermore, when he explains that "aw the music plays through me" and that he is "jist the conduit," 6 Zaf raises the challenge of hybridity, and the difficulty of unifying these tongues. As such, Psychoraag exposes the obstacles to achieving unity by exploring the ways in which language defines the self. In so doing, it probes how language may or may not translate into a meaningful sense of community, and raises important questions about language, nation, and identity in twenty-first century Scotland.

The fact that Saadi's novel is called a "raag" draws attention to the musical metaphor at its core. Raag, or raga, which means "color," "mood," or "atmosphere,"7 is the most celebrated form of Indian music. It consists of the "interplay of prescribed melodic movement and on-the-spot composition" and involves "taking a fixed composition, such as a song, and elaborating it with ornamentation, expansions, and improvised additions." "The Funnune Show is Zaf's raag: he works within the fixed format of a radio show-news, weather, ads, songs - and also indulges in on-the-spot improvisations. The songs that he plays create a community of listeners, but also define him: "His identity lay not in a flag 
Katherine Ashley $\quad \operatorname{IRSS} 36$ (2011)

or in a particular concretisation of a transcendent Supreme Being but in a chord, a bar, a vocal reaching beyond itself." 9 Perhaps because of his own hyphenated identity, he is uncertain of where his community is to be found, so he asks his listeners questions: "how are ye? Where are ye? Who are ye?" 10 The attempt to locate and connect with the Glaswegian community is also evident when he tries to "picture his audience." Zaf's public consists of all classes, and his list of listeners is comprehensive in its inclusiveness: "ex-gangstas"; "hot blades"; "young women on the brink"; "minicab drivers who, in another zameen, had been government ministers"; "doctors"; "nurses"; "lovers"; "members of wacky religious sects"; "madrasah junkies"; "off-duty, multiculturally-inclined strippers"; "curry-lovin polis"; "mothers whose babies wouldn't go down"; "city biviis with kisaan-heid hubbies"; "mitai-makers"; "multi-balti-millionaires"; "tramps"; "migrants"; "clerks"; "parkin wardens"; "aficionados of crossover"; "kebab-shop runners"; and "internet-crazed insomniacs."11 The fact that this community -and Zaf himself - exists in a state of struggle is apparent in the language itself, for English, Scots and Urdu collide in these descriptions, and the text as a whole is expressed in "weird English," a term that designates vernacular Englishes spoken (and written) by polycultural writers. ${ }^{12}$

Zaf's late-night audience is drawn together through music, through his playlist, and through his voice. This is consistent with the notion of a raag, which, according to Saadi, results in an osmosis-like exchange: "Personalised descriptions of a raag enable a musician to meditate on its characteristics and to unite his or her personality with a particular mood and, thereby, instil the same mood in the audience."13 Thus, by listening to The Funnune Show, Zaf's listeners become Funnunies, which suggests that it is only in madness and disorder that any accurate sense of community identity can be found. While the community Zaf evokes seems to counter the more exclusionary aspects of certain types of 
nationalism, there is no way of knowing whether this demographic is real, or simply ideal. Either way, because Zaf believes that "everybody wis a fuckin nomad and the borders were all closed,"14 his goal is to transcend musical, cultural, and political divisions:

Ye're listenin tae The Junnune Show an thenight-Ah'm soarry, this mornin - we're playin a real mix ae auld an new, of Eastern and Western an aw points in between. An beyond. Or, tae be mair accurate, the soangs that let us hear the truth ae the fact that the waruld is aw wan. That thur's nae 'East' and nae 'West' - that's jist a great big lie cooked up by those who, even if they wantit tae, could nivir hear the real music. ${ }^{15}$

Like Saadi, Zaf is "striving for unity," 16 a way to create a melody out of the "atonal choir of his life." ${ }^{17} \mathrm{He}$ searches for an impossible multiculturalism and, consistent with the spiritual or transcendent possibilities of the raag, this can only happen when borders dissolve and all dialectic disappears: "The songs were meldin into one another - they were losin their borders. For Zaf, if not for Scotland, the outside and the inside were mergin and that wis scary." 18 What he seeks in life, he finds in music: "In places, the notes would merge and, from somewhere, there would arise a third tune, one that nobody had ever written but which sounded better than either of its component parts." 19 Zaf's idealized "third tune" is no Blairite "third way" compromise, but a new level of awareness in which competing songs create a sort of Pure Song.

Despite Zaf's impressive roster of imagined listeners, his narrative appears to be driven by an overwhelming sense of not belonging. Unlike his girlfriend, Babs, who carries her homeland with her - "She'd been brought up in the deep south, in Galloway, where she had been surrounded by the land and the sea. She carried them with her wherever she went. The hills and the ocean breathed in her head"20-Zaf is 
without a spiritual connection to the soil of his two homelands and thus, he fears, without soul. His family's Pakistani roots are age-old - "The myths of his forefathers stretched back more than three millennia" 21 - but he is severed from these myths, cut off geographically from the land that gave birth to them and to his parents. Zaf describes himself in musical terms as "a sample of Pakistan, thrown at random into Scotland, into its myths. And in Lahore [as] ... a sample of Glasgow in the ancient City of the Conquerors." 22 As in the case of Rushdie's Indian-born, U.K.-dwelling writers who, when they "loo[k] back at India, $\mathrm{d}[\mathrm{o}]$ so through guilt-tinted spectacles,"23 Zaf's relationship with his two homelands is fraught with ambiguities. When he visits Pakistan, he is filled with "guilt," and the "feelin that he had done somethin not quite right but what that somethin might have been he had never been able to grasp." ${ }^{24} \mathrm{He}$ has "seldom been (back) to Pakistan":25 the subcontinent is not home, but "home,",26 and Glasgow is described as "apna shehron,"27 our city, a city he shares with Glaswegians of all national and ethnic origins. As the parentheses and quotation marks and italicized Urdu demonstrate, Zaf's relationship to both Scotland and Pakistan is uncertain and always qualified.

It is precisely because Zaf lacks roots in either Scotland or Pakistan that he searches for a fixed identity, for psychical, emotional, and linguistic wholeness. It is in part through music that this search takes place: "Good music ... filled your world. It completed you." 28 It is, of course, apposite that his music-inspired search should take place in Scotland, a so-called nation without a state. Establishing roots and identity in a stateless nation that is part of a larger political union, and which has historically played the role of both colonizer and colonized, conqueror and victim, is surely more complex than integrating or assimilating oneself into the dominant British (read: English) culture of the former colonial empire. Indeed, according to Alan Bissett: 
the Scots-Asian experience is one of three-fold colonisation: by white Scotland, by England, and by Britain's current self-colonisation under the aegis of American imperialism. Saadi explores the complexities of cultural integration as experienced by immigrant populations in a host country still grappling with its own 'postcolonial' crisis. ${ }^{29}$

The fact that the (sub-)community to which Zaf supposedly belongs has not altogether successfully put down roots in Glasgow, and is still marginalized, is proven by the fact that the radio station at which he works is transitory - the novel takes place on the last night of its three-month license to broadcast. Once Radio Chaandni stops broadcasting, the only alternative will be to listen to "Radio Sunset, the MiddleEngland-based Asian station that controlled most of the airwave franchise and which had been founded by some guy with janglin gold bracelets and a big blue swimmin pool in a hot place." 30 As a franchise driven by commercial forces and middle-of-the-road "Asianness," and directed from somewhere outside Britain, Radio Sunset is hardly likely to transcend conventional identity politics. Moreover, when Zaf reflects on the fact that Radio Chaandni is a specifically Asian station, his awareness of how communities are formed chimes with Benedict Anderson's notion of the "imagined community" and also with Salman Rushdie's contention that exiled or immigrant Indian writers "almost inevitably ... create fictions, not actual cities or villages, but invisible ones, imaginary homelands, Indias of the mind": 31

Well, after all, it is an Asian station, he thought. All the bits, past an future, that daily jostled and sang the state of Asianness into being, that reconstructed somethin that wasn't real from somethin that wis. [...] An, like some white-walled cavern chapel, Radio Chaandni 
Katherine Ashley $\quad$ IRSS 36 (2011)

bellowed out its hymns into the unlistenin darkness of Glasgow. ${ }^{32}$

The "unlistenin darkness" out of which "Asianness" is born in Glasgow does not conjure positive images of community identification. Indeed, music is not necessarily a force for fashioning a nation here, for any mystical communion between individual and society is denied Zaf, if not others, for the very reason that the songs he has been playing on-air up to this point have been exclusively Asian, ghettoizing both the music and his listeners. Zaf's white, Scottish born-and-bred girlfriend also recognizes these tensions: she dislikes the "intense exclusive Asianness" of the station, and the fact that it seems to "reve[1] in a kind of aural subcontinental architecture." "33 The link between music and collective space is clear: music builds the community and gives it a physical, material presence - fulfilling a legitimate need for a figurative room of one's own in a multicultural context. ${ }^{34}$ Through music, Zaf attempts to "redraw aw the maps" so that in the morning listeners and disc jockey alike "willnae recognise the waruld." 35 But not only can songs build cities in this reading, they are aural symbols of equality: Glasgow is "a great auld city. Iviry brick, iviry slice ae stane wis carved in the shape ae equality. Iviry block wis cut wi a soang." "36 For this reason, Zaf wants to "turn life intae music." 37 The inherent contradiction is that if Glasgow were, in fact, built upon equality, individuals like Zaf would not feel the need to redefine themselves, and Radio Chaandni itself would lose its raison d'être.

It is significant in this regard that what distinguishes the closing night of the Funnune Show from all previous broadcasts - and what therefore gives the novel its premiseis the very fact that Zaf alters the format of the final transmission so that the playlist does not reflect a particular type of music; indeed, there is no playlist as such in place before the broadcast begins: "he had left everythin to 
chance or whim or need." 38 Instead, in an effort to overcome the divisions within himself - North/South; West/East; Scottish/Pakistani; white/black; English/Scots/Urdu-he chooses the songs as he goes along, and his unstructured reflections on them constitute his raag and recreate his mood. The last night is a musical improvisation, a community-inbecoming, a bridge: "Mibbee that wis what this night wis about, the stuff he wis playin, it wis a first for a South Asian radio station - mibbee he wis tryin, single-handedly, to build a bridge of cantilever guitars, of sound, between himself [East/South/Asian] and Babs [West/North/European]."39 For Zaf, the type of "deep, horizontal comradeship" 40 of which Benedict Anderson writes can only exist in and through music that is not specific to a particular soil: "In music," Zaf states, "the divisions were all artifice, unity wis reality - in life, it wis the other way round." 41 After three months of playing exclusively Asian music, he ultimately resists the generic and cultural segregation of the radio station, perhaps because he "hate[s] bein defined by his status of bein other - felt trapped by that whole thing." ${ }^{2}$ The playlist for his final show, which is included as an appendix to the novel, is indicative of his catholic tastes in which binary distinctions and hyphenated identities are ultimately overcome. And when Zaf looks at the playlist during the show's final hour, he sees that "the meanings of the words had grown less distinct with each note of every song he had played." 43 Music supplants language, until the words representing the songs blend into an inky blur.

As an ethnology graduate, Zaf is acutely aware of the links between language and identity, and of his own contradictory feelings towards both. He is searching for wholeness and neutrality, but neutrality depends on definitions and borders, drawing lines between self and others, something that he refuses to do and is reluctant to accept. The final funnune Show is therefore an attempt to integrate many songs and many languages into one overarching Song or Language, and to confront contradictions head on. Identity, 
for Zaf, is a process of continual translation, a continual figurative search for what Walter Benjamin calls "pure language," 44 not a refusal to translate; a hope that there exists a state in which translation is unnecessary because "the inaccessible realm of reconciliation and fulfilment of languages" 45 has been reached. It is only on-air, through his raag, that Zaf manages to come close a state in which he, following Benjamin, recognizes that "languages are not strangers to one another, but are, a priori and apart from all historical relationships, interrelated in what they want to express." 46

Psychoraag thus offers a twenty-first century postcolonial response to the contradictions and difficulties inherent in, to borrow from Walt Whitman, "contain[ing] multitudes." 47 Since the union of the crowns and parliaments, the English-language tradition has dominated print-culture in Scotland, but the country has nevertheless been described, by Iain Crichton Smith, as "three-voiced,"48 meaning that it has literary traditions in Standard Scottish English, Gaelic and Scots - Scotland itself contains multitudes. Novels like Saadi's extend Scotland's literary and linguistic borders further still; as a result, while Scotland may be a nation without a state, the "intrinsically polyglot demotic" 49 of its cities is increasingly being reflected in texts that privilege heteroglossia over the monologue that Standard (or standardized) English can be. ${ }^{50}$ Accordingly, Psychoraag begins with a series of Muslim, Sikh, and Hindu greetings, expressed in Urdu, that sit beside references to Glasgow geography, and the whole is expressed in vernacular, which distances the text from literary norms and crosses textual, cultural, and linguistic borders. Written in a combination of first and third person narration, the novel overflows with voices, but the majority - certainly the on-air passages - is narrated in Glaswegian. ${ }^{51}$ The book opens with a demonstration of multiculturalism that underscores its local/global dynamic and is as linguistically challenging as 
other well-known contemporary opening gambits, such as Trainspotting's "The sweat wis lashing oafay Sick Boy":52

Salaam alaikum, sat sri akaal, namaste ji, good evenin oan this hoat, hoat summer's night! Fae the peaks ae Kirkintilloch tae the dips ae Cambuslang, fae the invisible mines es Easterhoose tae the mud flats ae Clydebank, welcome, ivirywan, welcome, Glasgae, welcome, Scoatland, tae The Junnune Show. Sax oors, that's right, sax ooors, ae great music, rock an filmi an weird, weye-oot-there happenins an ma rollin voice. Whit a combination, eh? It's wan ye cannae resist.

Wance ye tune in, the dial sticks. Aye, Ah'm in control ae yer radio sets - aw the music plays through me. Ye're oan ma wavelength an that's a pretty weird place tae be! ${ }^{53}$

In addition to Standard (Scottish and British) English and Scots, the novel contains Arabic, Farsi, French, Gaelic, Hindi, Irish Gaelic, Old Persian, Punjabi, Spanish, Turkish, and Urdu. Although Saadi wanted all words to be graphically equal, ultimately words in languages other than Scots and English ended up being italicized at the behest of his publisher. What is more, the novel contains an extensive glossary (which includes Scots words). "Far from being a regressive linguistic-political statement," Saadi contends, "the glossary in Psychoraag represents both a hypertextual, etymological exposition and a creative deviance from the psychological intensity of the narrative itself." 54 The italics and the glossary draw attention to the words as such, and serve to highlight the multiple languages in use by Zaf. Thematically, this is fitting because rather than presenting all languages as existing on an even plane, it underscores the uneasy relationship the various languages have in the text.

The novelty - and challenge - of Psychoraag's language $(\mathrm{s})$ becomes doubly apparent in translation. In 
French, for example, the Scottish voice that dominates the narrative is normalized - back translating it would result in Standard English-but the Urdu greetings retain their foreignness:

Salaam alaikum, sat sri akaal, namaste ji. Bonsoir et bienvenue à tous. Merci de nous rejoindre par cette nuit d'été chaude, chaude, chaude! Depuis les sommets de Kirkintilloch jusqu'aux vallées de Cambuslang, depuis les galeries de mines d'Easterhoose jusqu'aux marécages de Clydebank, bienvenue à tous, bienvenue Glasgow, bienvenue à toute l'Ecosse, bienvenue au Junnune Show. Six heures, eh ouais, six heures de bon son, de rock, de filmi, de délires de l'au-delà, en compagnie de ma voix chaude et suave. Pas mal comme programme, hein? Cherche pas à résister: quand on est branché sur ma fréquence, y'a pas moyen de se déconnecter. Eh ouais, j'ai pris le contrôle de ton poste de radio - c'est moi qui choisis ta zique. T'es sur ma longueur d'ondes et je te préviens, c'est un endroit plutôt zarb! Vous êtes sur quatre-vingt-dix-neuf-point-neuf FM Radio Chaandni. ${ }^{55}$

While Saadi's text displays great linguistic flexibility and looseness, the translation - although it includes colloquialisms like "zique" (musique) and "zarb" (Lyon verlan for "bizarre"), whose initial zeds are more foreign than French - seems more formal, something that is emphasized by rules of agreement that must be followed in French, but also by the addition of phrases like "bienvenue à tous" and "merci de nous rejoindre." Most telling in terms of the present argument, however, is the fact that the French translation of Psychoraag treats oral Glaswegian as a standard written language, and translates it into standard written French which is then peppered with slang and phonetic renderings of relaxed pronunciation ("ouais" and "y'a"). In addition, the initial 
Urdu greetings, which do belong to a majority language (there are 400 million Urdu speakers), remain "other," untranslated and italicized in French, while the Scots narration is normalized. What this reveals is that it is easier to demonstrate that Urdu is "other" in a Scottish context than it is to translate the fact that Scots narration is "other" in the context of a so-called English-language novel by a Scot. In other words, the most distinctly local aspect of Saadi's text, the play of immigrant languages against a dominant Scottish voice, is lost when it is transferred to another cultural and linguistic context.

The consequence of the visibility (or audibility) of many tongues is that language, the means by which Zaf mediates between different versions of himself, is synonymous with madness. As Saadi explains, "every tongue talks into being a universe; so, allowing tongues to dance up close with one another results in a raag of lunacy, a cosmic song." 56 While Psychoraag is undeniably anchored in the Glasgow vernacular, there is no question that Zaf himself has access to many worlds, and is a kind of radio receiver of the world's languages. ${ }^{57}$ Yet, in receiving these languages, his voice does not create a unified self or nation, but is so individual, so local in its internationalism, that it verges on idiolect. Language becomes chaotic madness and contradictions become difficult to contain. As a result, Zaf lives in a personal state of translation: "he had forgotten how to just live - to exist in the physical and not as disembodied words." 58 Communicationand by extension, community - becomes unstable.

Benedict Anderson argues "much the most important thing about language is its capacity for generating imagined communities, building in effect particular solidarities." 59 With this in mind, to what extent can it be said that language for Zaf is synonymous with identity and community? Zaf's parents' exile means that he cannot speak fluent Urdu: he "never learned his own mother tongue - not properly so that he would have been able to converse in it, to construct 
meanin from chaos." 60 His parents speak to him in Standard English. ${ }^{61}$ As a consequence, he is alienated from his Pakistani linguistic and cultural origins, but also from fellow Glaswegians. Furthermore, when listening to a conversation that he assumes is taking place in Urdu, Zaf comments that "it wis like he wis listenin to a foreign language. Punjabi mibbee." 62 He only realizes afterwards that the language being spoken is English. Language is linked to identity and community, certainly, but only insofar as it makes multiple selves and communities possible. Like a raag, which is never performed the same way twice, identity (and community) here is conceived as a flexible process rather than as a predetermined state of being. In what is perhaps a nod to Frantz Fanon, who wrote "in the world in which I travel, I am endlessly creating myself," 63 Zaf remarks that "You had to make up your own version of everythin. Every day, you had to be a wee creator." ${ }^{4}$ All identity, all language, is therefore a mask, and the self is always other. On The Junnune Show, Zaf is the disc jockey, presenting music and creating his raag, but he has other personae, too. He is also the voice of the news, the weather, and the ads: "It wasn't his voice, of course. Well, it wis but not the same voice." 65 The question is whether these voices hide the same person: will removing one mask simply reveal another?

As The Funnune Show is Zaf's raag, so Psychoraag is Saadi's. The novel operates as part of an overarching discourse on nationality and identity. While Zaf's aspirations seem hopelessly idealistic, the fact that the novel exists demonstrates that it is possible to write Zaf's raag into existence, and write an oral text. As in other contemporary Scottish novels, such as Trainspotting, in Psychoraag "was" more often than not becomes "wis," "I" becomes "Ah": which suggests a breath of air, an openness to the world. What is more, the spelling of the word "Scotland" changes throughout, demonstrating that "Scotland" is no more a defined space or a fixed idea than "Scottish" is a fixed 
identity: "Scotland," "Scoatland," and "Scoatlan";66 "sunny Scotland," "Sooth Asian Scotland," "bone fide Scottish," "Scoa'ish stuff." 67 These orthographical modifications are indicative of linguistic freedom, of the possibility of creating oneself through a local language that has no standard written form. Seeing a local language in print is itself a means of creating a community, however: as Evelyn Nien-Ming Ch'ien comments, "vernaculars used by weird-English authors have existed for decades, but the act of transcribing establishes the community-speak in a permanent way." 68 For this reason, the risk of falling into idiolect disappears once the vernacular makes the transition from spoken word to written word. There is a danger in this, though: giving Zaf's language a textual life necessarily stabilizes it, and stabilizing Zaf's instability undermines the very freedom that both Zaf and Saadi are attempting to achieve. Theoretically, then, the most liberating thing to do would be to refuse to standardize Scottish voices so that Scottish texts and Scottish identity become synonymous with moving beyond conventional definitions of self, other, community, and nation.

The Funnune Show allows Zaf to speak in a primarily Glaswegian voice and play Asian (and other) music to fellow (Asian) Glaswegians. But because the Scottish and Asian voices are both "other" in a British context, Psychoraag's Scottish vernacular is just as much a political statement as is its representation of Asian community radio. As Saadi has explained: "I aimed to debunk the dominant LondonOxbridge text, the shrine by which even the most supposedly progressive narratives are framed, and to shatter the mirror of decorum, linguistically, culturally and in terms of a regressive class dynamic that defines most corporately published literary novels in the UK." 69 These comments are linked to the author's notion of "Scottishness" as a mode of perception. "Scottishness," he claims, "is a metaphor through which I perceive other things." 70 This is no mere authorial pose: Saadi was born in England of Afghani-Pakistani immigrant parents. 
That Psychoraag was marginalized in an English context is proven by the fact that while it was nominated for the IMPAC Dublin literary award in 2006, shortlisted for the Edinburgh-based James Tait Black Memorial Award (the oldest literary prize in the United Kingdom) in 2004, and won an American PEN award in 2005, it "was rejected by almost all major London publishers before eventually finding a small, entrepreneurial publisher in Edinburgh who, with the cooperation of the Scottish Arts Council, was willing to take a risk."71 These tributes testify to the success of Saadi's raag beyond the centre of the United Kingdom, while its lack of success in England could be attributed to the fact that it not only challenges the English language and presents no easy solutions to the idea of Asianness in Britain, but militates against the type of "safe multiculturalism"72 that Saadi believes prevails in London publishing circles.

As the end of the show approaches, Zaf addresses his listeners in an uncharacteristic manner: "Good morning, everybody. Hello. This is Zafar. You know how it's spelt."73 But this Standard English greeting quickly gives way to a change in voice: "Zaf slipped back one last time- - his face, his body, his soul slipped back in to jargon." ${ }^{\prime \prime 4}$ What does this final tussle between English and the vernacular indicate? Does slipping "back in to jargon" signal a reversion to a primitive, savage, uneducated state? It may appear that way given that the slippage is recounted by a third-person Standard English voice. Or is the fact that both the outer shell and the inner heart - "his body" and "his soul" - slip "in to jargon" a sign that Zaf's on-air voice, with its mix of standard and nonstandard languages and forms, is the closest he will come to overcoming the divisions within himself? And what of Zaf's on-air English? Coming at the end of a six-hour broadcast, a three-month radio run, and a 400-page book, it seems incongruous. But it is also appropriate insofar as it reinforces the fact that he, like Rushdie's émigré writer, is doubly alienated: ${ }^{75}$ he is both Scottish and Asian, living in a 
seemingly United Kingdom that is dominated by English voices. In order for either of his two halves to prosper beyond the radio show, a Standard English voice must be adopted and the "thoosand tongues" must be silenced: "The music's over - the journey, the madness. No more Weather, no more News. There is nowhere left to run. This is where it ends. Here, in this cubicle, before this mike. Through this voice."76 The journey ends and the raag finishes when he speaks through the mask that is the English language. The "madness" of the show then perhaps consisted in believing that things could be otherwise and that English could be metaphorically overcome.

The airwaves facilitate the connection between speaker and audience by carrying the breath of the one to the mouth of the other. When Zaf lets the "airwaves fill with quiet," he announces to listeners: "Ah'm sittin here listenin tae yous. Ye're breathin ma breath."77 Likewise, after he has systematically and almost obsessively stroked the studio's sound cones, his "skin ... becomes electric," and his hands and feet are transformed into "tactile receivers, synthetic skins through which he felt he wis able to perceive of everythin"78 - he is, as it were, a Whitmanesque body electric. Indeed, this passage recalls Song of Myself, where the speaker has "instant conductors" that "seize every object and lead it harmlessly through" him. ${ }^{79}$ But Zaf "perceives" while Whitman's speaker "seizes"-the difference lies in recognizing the other's existence versus asserting ownership. Saadi embraces weird English and posits individual and shared identity as a raag-like invention. There is the suggestion that Zaf's sense of transcendent self will only exist so long as the music plays and the raag continues. He asks his listeners:

Whit happens tae a particular wavelength aifter a radio station hus stopped usin it? Where dae aw the wurds go? Eh? Does it jis fade away or does it refuse tae disappear? 
Does it grab the invisible air an take oan a life ae its ane so that, even aifter the radio station's door hus been closed an bolted, the voice goes oan? An the music? Think aboot that, guid people. ${ }^{80}$

The raag ends with Zaf's final broadcast. Once the show is over, disunity and discordance will return and Zaf will have to translate his many voices into a Standard English voice. ${ }^{81}$ Thus, Saadi's novel is no speech act designed to construct a nation, but a commentary on the inherent limitations of monologic language. It is a call for a new way to sing, and to write about, identity, a way to "redefin[e] old modalities." 82 It is also a way for Scotland's literature to assert its internationalism while expressing itself in the country's many languages. As such, in its depiction of one individual's struggle, Psychoraag engages with the wider issue of the community-building powers of both music and language, challenges the concept of ordered nationality, and in so doing is representative of what Carla Sassi refers to as Scottish literature's "protean, polyphonic tradition." 83 


\section{Notes}

${ }^{1}$ Walt Whitman, Song of Myself, in The Complete Poems, ed. Francis Murphy (Harmondsworth: Penguin, 1986), 63-124, 89, sec. 25.

2 Suyahl Saadi, Psychoraag (Edinburgh: Chroma, 2005), 102.

${ }^{3}$ Saadi is not the only contemporary Scottish author who uses music as a means of exploring identity: Jackie Kay uses jazz in her 1998 novel,

Trumpet.

${ }^{4}$ Saadi, Psychoraag, 173.

${ }^{5}$ Ibid., 66.

${ }^{6}$ Ibid., 291.

${ }^{7}$ Walter Kaufmann, Involvement with Music: The Music of India (New York: Harper's College Press, 1976), 6.

${ }^{8}$ George E. Ruckert, Music in North India: Experiencing Music, Expressing Culture (New York: Oxford University Press, 2004), 7 and 53.

${ }^{9}$ Saadi, Psychoraag, 210.

${ }^{10}$ Ibid., 1.

11 Ibid., 19.

12 This term was coined by Evelyn Nien-Ming Ch’ien. See her Weird English (Cambridge, MA: Harvard University Press, 2004).

13 Saadi, Psychoraag, 428.

14 Ibid., 329-30.

15 Ibid., 132.

16 Suhayl Saadi, "Songs of the Village Idiot: Ethnicity, Writing and Identity," Suhayl Saadi, $<$ http://sarmed.netfirms.com/suhayl/NEW/articles_ essays/village_idiot/index.htm>.

17 Saadi, Psychoraag, 4.

18 Ibid., 195.

19 Ibid., 239.

20 Ibid., 11.

${ }^{21}$ Ibid., 8.

22 Ibid., 227.

23 Salman Rushdie, "Imaginary Homelands," in Imaginary Homelands: Essays and Criticism 1981-1991 (London: Granta Books, 1991), 9-21, 15.

${ }^{24}$ Saadi, Psychoraag, 57. 


\section{Ibid., 207. \\ 26 Ibid., 23. \\ 27 Ibid., 209. \\ 28 Ibid., 239.}

${ }^{29}$ Alan Bissett, "The 'New Weegies': The Glasgow Novel in the TwentyFirst Century," in The Edinburgh Companion to Contemporary Scottish Literature, ed. Berthold Schoene (Edinburgh: Edinburgh University Press, 2007), 5967,64 .

30 Saadi, Psychoraag, 164-65.

31 Rushdie, "Imaginary Homelands," 10.

32 Saadi, Psychoraag, 22.

33 Ibid., 92.

34 As Adorno argues, "politicians and other authorities ... regard [music] as a cohesive social force, as something capable of creating the illusion of immediate community within a reified and alienated society" (Theodor W. Adorno, Sound Figures, trans. Rodney Livingstone [Stanford: Stanford University Press, 1999], 3). Psychoraag shows that it is, indeed, just an illusion.

35 Saadi, Psychoraag, 208.

36 Ibid., 348.

37 Ibid., 210.

38 Ibid., 3.

39 Ibid., 92.

40 Benedict Anderson, Imagined Communities: Reflections on the Origin and Spread of Nationalism (London: Verso, 2006), 7.

41 Saadi, Psychoraag, 327.

42 Ibid., 45.

43 Ibid., 396.

${ }^{44}$ Walter Benjamin, "The Task of the Translator," in Illuminations, ed. Hannah Arendt, trans. H. Zohn (London: Fontana, 1992), 70-82, 74.

45 Ibid., 76.

${ }^{46}$ Ibid., 73.

47 Whitman, Song of Myself, 123, sec. 51.

48 Douglas Gifford and Alan Riach, eds., Scotlands: Poets and the Nation (Manchester and Edinburgh: Carcanet/Scottish Poetry Library, 2004), 245. 
${ }^{49}$ Kirstin Innes, "Mark Renton's Bairns: Identity and Language in the Post-Trainspotting Novel," in The Edinburgh Companion to Contemparary Scottish Literature, ed. Berthold Schoene (Edinburgh: Edinburgh University Press, 2007), 301-9, 302.

50 This is not to say that Standard English plays an unimportant role in Scottish writing and Scottish life. Indeed, Standard English is not always limiting, nor indeed can it adequately or comfortably be labelled as "foreign" in a Scottish context. Furthermore, as an anonymous reviewer of this article pointed out, many of the polyphonic effects that novels like Psychoraag display depend on English in its role as "substrate" language. ${ }^{51}$ As Anna Battista points out, the Standard English passages relate largely to Zaf's parents' story, "almost to reflect the time when they left [Lahore] and their own idea of what the English language sounded like." Anna Battista, "Facts and Fictions: Interview with Writer Suhayl Saadi," New Writing 3, no. 2 (2006): 118-22, 119.

52 Irvine Welsh, Trainspotting (London: Minerva, 1993), 3.

53 Saadi, Psychoraag, 1.

54 Suhayl Saadi, “In Tom Paine's Kitchen: Days of Rage and Fire," in The Edinburgh Companion to Contemparary Scottish Literature, ed. Berthold Schoene (Edinburgh: Edinburgh University Press, 2007), 28-33, 29-30.

55 Suhayl Saadi, Psychoraag, trans. Jean-Charles Perquin and Samuel Baudry (Paris: Editions Métailié, 2007), 1.

56 Saadi, "In Tom Paine's Kitchen," 31.

57 This is precisely what is missing in the French version: Zaf's key statement "aw the music plays through me" is literalized in translation, and its metaphorical or figurative implications are absent. "C'est moi qui choisis ta zique" (It's me who's choosing your music") acknowledges his control over the songs that are played on air, but does not suggest that he is a sort of human radio receiver.

58 Saadi, Psychoraag, 211.

59 Anderson, Imagined Communities, 133.

60 Saadi, Psychoraag, 246.

${ }^{61}$ Zaf presents Urdu as his mother tongue, when in fact he usually speaks English at home. On the nature of the "mother tongue", see Ch'ien:

"When they [weird English writers] discover that their language was never 'theirs' to begin with, they are awakened to the arbitrariness of identity and of their given language, which they called their 'mother' tongue."

Ch'ien, Weird English, 33.

62 Saadi, Psychoraag, 246. 
${ }^{63}$ Frantz Fanon, Black Skin, White Masks (London: Pluto, 1986), 229.

64 Saadi, Psychoraag, 230.

65 Ibid., 10

66 Ibid., 21, 1, and 208.

67 Ibid., 204, 84, 30, and 30.

68 Ch'ien, Weird English, 4.

69 Saadi, "In Tom Paine's Kitchen," 30. To illustrate the point Saadi is attempting to make, one might compare Psychoraag's linguistic and "psychological intensity" (Saadi, "In Tom Paine's Kitchen," 29) to the linguistic decorum of Amit Chaudhuri's Afternoon Raag, set in Oxford and published in London by Heinemann in 1993.

70 Suhayl Saadi, "Being Scottish," Suhayl Saadi, <http://sarmed.netfirms.com/suhayl/NEW/

articles_essays/being_scottish/index.htm>. "Scottishness" as a metaphor disappears in translation, however: translation renders the difference of the italicized words, but it cannot render the otherness of the language that dominates the narrative. In a sense, this is positive, because it implicitly gives majority status to Glaswegian, which in turn extends the borders of Scottishness, globalizing the local (Glaswegian) dialect, and unifying the character.

${ }^{71}$ Suhayl Saadi, "PEN Oakland Josephine Miles Literary Award 2005 for Psychoraag," Suhayl Saadi, <http://sarmed.netfirms.com/suhayl/NEW/speeches/pen/index.htm>. Audio version: http://www.sarmed.netfirms.com/suhayl/suhayl_ penSpeech.mp3 $>$. The novel was also shortlisted for a National Literary Award in Pakistan in 2005.

72 Saadi, "In Tom Paine's Kitchen," 29.

73 Saadi, Psychoraag, 415.

74 Ibid., 415.

75 In "Imaginary Homelands," Rushdie writes of émigré Indian writers: "Our identity is at once plural and partial. Sometimes we feel that we straddle two cultures; at other times, that we fall between two stools" (Rushdie, "Imaginary Homelands," 15).

76 Saadi, Psychoraag, 415.

77 Ibid., 88.

${ }^{78}$ Ibid., 62.

${ }^{79}$ Whitman, Song of Myself, 91, sec. 27.

80 Saadi, Psychoraag, 378. 
${ }^{81}$ As Ch'ien notes, "because weird English possesses the extra dimension of a foreign language, it requires not only interpretation but also translation" (Ch'ien, Weird English, 6).

${ }^{82}$ See Saadi, "Songs of the Village Idiot": "I hear the reader as a musician, not a musician in the Western classical tradition, but a jazz musician who 'breaks and enters' the text at will and who, through the act of reading, redefines old modalities."

83 Carla Sassi, Why Scottish Literature Matters (Edinburgh: The Saltire Society, 2005), 168. 